\title{
Exosomal Heat Shock Proteins as New Players in Tumour Cell-to-cell Communication
}

\author{
Review Article
}

\author{
Claudia Campanella ${ }^{1,2, *}$, Celeste Caruso Bavisotto ${ }^{1,2}$, \\ Antonella Marino Gammazza ${ }^{1,2}$, Dragana Nikolic ${ }^{1}$, Francesca Rappa ${ }^{1,2}$, \\ Sabrina David ${ }^{1,2}$, Francesco Cappello ${ }^{1,2}$, Fabio Bucchieri ${ }^{1,2}$ and Stefano Fais ${ }^{3}$ \\ 1 Department of Experimental Biomedicine and Clinical Neurosciences, Section of Human Anatomy "Emerico Luna", \\ University of Palermo, Palermo, Italy \\ 2 Euro-Mediterranean Institute of Science and Technology, Palermo, Italy \\ 3 Department of Therapeutic Research and Medicine Evaluation, Istituto Superiore di Sanità, Rome, Italy \\ * Corresponding author E-mail: claudia.campanella@unipa.it
}

Received 19 Mar 2014; Accepted 23 May 2014

DOI: $10.5772 / 58721$

(C) 2014 The Author(s). Licensee InTech. This is an open access article distributed under the terms of the Creative Commons Attribution License (http://creativecommons.org/licenses/by/3.0), which permits unrestricted use, distribution, and reproduction in any medium, provided the original work is properly cited.

Abstract Exosomes have recently been proposed as novel elements in the study of intercellular communication in normal and pathological conditions. The biomolecular composition of exosomes reflects the specialized functions of the original cells. Heat shock proteins (Hsps) are a group of chaperone proteins with diverse biological roles. In recent years, many studies have focused on the extracellular roles played by Hsps that appear to be involved in cancer development and immune system stimulation. Hsps localized on the surface of exosomes, secreted by normal and tumour cells, could be key players in intercellular cross-talk, particularly during the course of different diseases, such as cancer. Exosomal Hsps offer significant opportunities for clinical applications, including their use as potential novel biomarkers for the diagnoses or prognoses of different diseases, or for therapeutic applications and drug delivery.
Keywords Extracellular Vesicles, Heat Shock Proteins, Cell Communication

\section{Introduction}

\subsection{Cell-to-cell communication}

Cellular communication is used by multicellular organisms to organize and coordinate the activities and the development of various organs and tissues [1]. In order to maintain cellular homeostasis or to respond to pathogens in the extracellular milieu, cells often exchange information through direct cell-to-cell contact or by secretion of soluble factors, either via ligand-receptor interactions or cellular 'bridges', such as nanotubes [2]. The cells interact with other cells through membrane surface molecules or by secreting several types of molecules such as soluble proteins, amino acids, fats, 
steroids and gas. These molecules can activate the target cells by interacting with the cell surface receptors [1]. Recently, it has been shown that cells can also communicate through the direct exchange of nucleic acids. New evidence has shown that circulating miRNAs may be important in intercellular communication; in particular, they may induce gene silencing in the target cells $[3,4]$. In addition to soluble molecules, cells can also send information through cell junctions and adhesion contacts, which can act within the same cell in which they are produced, in neighbouring cells, or even over long distances in an endocrine manner [5]. In the past two decades, another mechanism for intercellular communication has emerged involving the intercellular transfer of extracellular vesicles (EVs) [1]. Abundant evidence has validated a newly identified mechanism of intercellular interaction through lipid vesicles, in which phospholipid-enclosed vesicles are released into the extracellular environment that can bind the specific receptor to the target cells, and vescicles are be internalized by recipient cells [6]. The release of EVs is a well-conserved evolutionarily mechanism that cells use to exchange bioactive proteins, lipids and nucleic acids. EVs released from cells are heterogeneous in origin and size, and include those derived from the endosomal membrane cell compartment, released by exocytosis after the fusion of multivesicular bodies with the plasma membrane, as well as those formed by direct budding of the plasma membrane $[2,7]$.

EVs were first characterized in hematopoietic cells. In 1967, Wolf observed these subcellular fractions ("microparticles"), which he described as "platelet dust" using electron microscopy [8]. Initially, it was thought that EVs were a mechanism of the depletion of the cytoplasm and a specific function of membrane reticulocytes. Indeed, EVs are rich in reticulocyte-specific proteins, transferrin receptor and devoid of some key plasma membrane proteins [9]. Increasing evidence supports the notion that each cytotype produces EVs (including $\mathrm{T}$ cells, B cells, dendritic cells, platelets, epithelial cells and cancer cells), which are essential players in intercellular communication and that they establish the ability of a cell to sense and adapt to environmental alterations $[10,13]$.

EVs are composed of a lipid bi-layer and contain multiple functional molecules derived from the cytosol of the donor cell, such as proteins (both transmembrane and luminal), lipids, RNAs, non-coding RNAs, microRNAs and retrotransposon elements [14]. EVs constitute a heterogeneous population that differs in cellular origin, size, morphology, antigenic composition and functional properties. They are classified into various categories based on their size and composition, for example, exosomes (40-100 nm), apoptotic bodies (>800 nm) [15], microparticles $(0.1-1 \mu \mathrm{m})$, prostasomes $(50-500 \mathrm{~nm})$ and tolerosomes $(\sim 40 \mathrm{~nm})$, factors that create confusion in the nomenclature [16]. In addition, isolating them is extremely difficult. In fact, in recent years, researchers have tried to improve the various EV isolation protocols [1]. In many past studies, EVs were isolated by differential ultracentrifugation, depending on their size and density, but isolation protocols have not been definitively standardized. Following differential ultracentrifugation, a complementary characterization procedure using biochemical markers and electron microscopy imaging techniques is essential [13]. Among the large group of EVs, exosomes have been most studied to date, because of their involvement in both pathological and physiological events as mediators of cell-to cell communication [16].

\section{Exosomes}

As described by Pan in 1983, it was initially thought that exosomes could be a mechanism for shedding the cytoplasm in maturing sheep reticulocytes [17]. In fact, exosomes are cell-derived vesicles that are secreted by all cell types and are also present in many body fluids such as blood, urine, cerebrospinal fluid, breast milk, saliva, bronchoalveolar lavage fluid, ascitic fluid and amniotic fluid [18]. Exosomes are released into the extracellular space after the merging of late endosomes with the cell membrane. Early endosomes become part of multivesicular bodies (MVBs), which undergo a maturing process that provides a gradual change in protein composition of the vesicles (intraluminal vesicles (ILVs). During this maturation process, the vesicles accumulated in the MVBs, can have three potential outcomes: 1) they may merge with the lysosomes, causing protein content degradation (e.g., in the case of receptors); 2) they may constitute a temporary storage compartment; 3) they may blend with the plasma membrane, releasing exosomes. Therefore, exosomes correspond to the intraluminal vesicles of MVBs. MVBs merge with the plasma membrane, resulting in exocytosis of the vesicles contained in MVBs; as such, vesicles maintain the same topological orientation as the plasma membrane [1, 19].

The endosomal sorting complexes required for transport machinery (ESCRT) are involved in exosome biogenesis and in their loading. Different evidence sources support the idea that ESCRT could assist in the sorting of ubiquitinated cargo proteins at the endosome membranes. The ESCRT-associated protein ALIX (apoptosis-linked gene 2-interacting protein X) can regulate this function [20]. Likewise, some evidence assumes that the sorting of proteolipid molecules to intraluminal vesicles functions independently of ESCRT. For example, in dendritic cells, during cognately antigenspecific CD4+ T cell interaction, the sorting of MHC II to 
exosomes occurs independently from MHC II ubiquitination and MHCII can be incorporated into detergent-resistant protein complexes of intraluminal vesicles, which are secreted as exosomes and transferred to the interacting T-cells [21]. Another alternative cargo selection, independent from the ESCRT mechanism, occurs through lipid affinity, which requires sphingolipid ceramide and depends on raft-based microdomains [2224].

Exosomes exhibit specific cell-type dependent content. It has been reported that their protein composition is similar to that of proteins found in plasma membranes, as well as in the endocytic or subcellular compartments of source cells and includes membrane proteins such as annexins [25]; cytoskeletal proteins (tubulin, actin) [26]; lysosomal markers (CD63, LAMP-1/2); enzymes [27]; death receptors (FasL, TRAIL) [28]; cytokines [29-31]; HLA class I/II [32] and some heat shock proteins (Hsps) $[33,34]$. It has been demonstrated that exosomes derived from various cell types contain a wide variety of RNA, including mRNA, miRNA, rRNA and tRNA [35-41]. The RNA present in exosomes has been termed exosomal shuttle RNA (esRNA) [39] and can be transferred to recipient cells where they modulate cells' genetic expression [41]. Exosomes might constitute an exquisite mechanism for local and systemic intercellular transfer, not only of proteins, but also of genetic information in the form of RNA [39].

Depending on the source cell, many different functions have been attributed to exosomes. They are involved in cell-to-cell information transfer [42], immune response [43], inflammation [44], coagulation [45], stem cell activation [46] and programmed cell death [47]. Exosomes can participate in cellular responses against stress. Clayton and colleagues [48] showed that exposing B-cell lines to heat stress results in a marked increase of Hsps expression by exosomes and in an increase in the quantity of exosomes produced. Given that exosomes can mediate the transfer of specific molecules, they may play a role in intercellular transmission in disease pathogenesis, including tumour development, viral infections and neurological diseases. For example, exosomes might carry viral proteins from the infected cells from which they are released, thereby playing a part in the intercellular dissemination of viral vectors, or in clearing viral proteins from infected cells $[49,50]$. Most studies have that many tumour cells release a large amount of EVs and those tumour-derived vesicles can carry proteins, lipids and nucleic acid that contribute to cancer progression [51]. In the case of many tumours, such as ovarian carcinoma, prostate cancer and pancreatic cancer, high levels of exosomes have been reported and these data suggest that exosomes could be important diagnostic and therapeutic tools [52-55]. Furthermore, neuronal exosomes can mediate the transfer of misfolded proteins, causing a transmission mechanism of systemic amyloidoses in neurodegenerative diseases [56, 57]. All these data show that exosomes are important players in various physiological and pathological processes, and could be useful for both diagnostic and therapeutic applications. Some evidence obtained with exosomes released by human cancer cells support the existence of at least two entirely different mechanisms through which exosomes may interact with target cells. One is mediated by interaction of a ligand (often expressed on the exosome membrane) and its receptor (often expressed on the cell plasma membrane). This was clearly demonstrated for death-receptors/ligands interaction, which always led to the triggering of cell death [58-60]. However, exosomes may fuse with the plasma membrane of the target cells, in turn transferring their content to the cell cytoplasm and possibly fusing with internal vesicles, too [61]. The exosomes taken up by target cells may well have an effect, as it has been shown for NK cell-derived exosomes [60], suggesting that exosomes can be used as real effectors of the natural immune response against either tumours or foreign agents [62].

\section{Hsps and exosomes}

Molecular chaperones are a group of proteins conserved during evolution and are involved in the maintenance of other "client" proteins in folded and active conformations in all cellular organisms [63-65]. These chaperones protect the proteome from the dangers of misfolding and aggregation by facilitating protein folding, complex assembly and refolding of partially denatured proteins; additionally, they also drive protein translocation across membranes and in the case of protein damage, toward degradation [58, 59]. Chaperonology is the science that studies molecular chaperones and pathological conditions in which chaperones become pathological factors, known as chaperonopathies. Chaperone therapy involves the use of chaperones in the treatment of chaperonopathies [63, 64]. Most Hsps are molecular chaperones with crucial functions in the biosynthesis, folding/unfolding, transport and assembly of other proteins [63-66]. They are classified into families by their molecular weights: Hsp100, 90, 70, 60, 40 and the 'small Hsps', which includes Hsp27 [65]. Hsps were initially described as a group of proteins that are induced by heat shock, as well as by other stressors [67]. The expression of Hsps is induced in response to a wide variety of stress conditions, such as hypoxia, ischemia, heavy metal or ethanol exposure and infections [68]. Interest in these molecules has increased in recent years due to many studies having indicated that these proteins are involved in many physiological mechanisms in normal cells, such as DNA replication and gene expression regulation [63]. Several mechanisms are responsible for the cytoprotective 
effect of Hsps [69]. Additionally, it has been demonstrated that Hsps have other roles, such as participation in immune system regulation [70, 71], cell differentiation [72], apoptosis and carcinogenesis [73-75]. The levels of many Hsps are elevated in various types of cancer and Hsp overexpression suggests a poor prognosis in terms of survival and response to therapy in some types of cancer [65]. Numerous studies have shown that Hsps are involved in cell transformation, metastasis formation and multidrug-resistance development [65, 74, 75]. Furthermore, several studies have reported that elevated levels of Hsps can protect malignant cells against therapy-induced apoptosis [65,69]. Hsps are traditionally considered intracellular molecules, but many studies have shown that they can also appear in extracellular locations or in the blood [76- 81 . Extracellular or membrane-bound Hsps can mediate immunological functions and may act as a potent danger signal, activating the immune system response [82]. Several years ago, some researchers hypothesized that exosomes may provide a secretory pathway, allowing cells to actively release specific Hsps [48, 83]. Exosomes are important in cell-to-cell communication; on the other hand, they are also considered to be key players in intercellular cross-talk [82]. Recent studies have validated this hypothesis by demonstrating that specific members of the Hsp family, such as Hsp70, Hsp90 and Hsp60, can be secreted by cancerous cells via the exocytotic pathway (Table 1) [13, 33, 84, 85].

Hsp70 and Hsp90 are classic cytosolic chaperonins and normally fulfil a cytoprotective role inside cells [89]. Hsp70 is actively secreted by different types of cells through non-classical protein secretory routes, including exosome pathways [84]. Extracellular Hsp70 exert immunomodulatory effects and play a key role in the immune response to cancer cells [85]. For example, microvesicles containing Hsp70 on their surface activate macrophages [90], or natural killer cells [86, 87] and play an important role in the regulation of vascular homeostasis [84]. Hsp90 $\alpha$ is released by invasive cancer cells via exosomes and its release enhances cancer cell migration [88]. In recent years, new data has revealed new extracellular roles for Hsp60. Hsp60 is considered a mitochondrial protein that is, together with its cochaperone Hsp10, essential for mitochondrial protein folding [74]. There is increasing evidence localizing Hsp60 outside of the cells, where it mediates interaction between immune cells and other body tissues [91]. In addition, much recent experimental evidence has demonstrated that Hsp60 can be localized in extramitochondrial sites [65]. In particular, it has been detected in the cytosol [92], intracellular vesicles [88], on the surface of normal and tumour cells [33,93] and in

\begin{tabular}{|c|c|c|c|}
\hline Tumoural Exosomal Hsps & Tumoural Cells Origin & Functions & Ref. \\
\hline \multirow[t]{7}{*}{ Hsp70 } & $\begin{array}{l}\text { Human Erythroleukemia } \\
\text { cells }\end{array}$ & $\begin{array}{l}\text { Immunomodulatory } \\
\text { functions }\end{array}$ & {$[85]$} \\
\hline & & & {$[85]$} \\
\hline & Breast carcinoma cells & & \\
\hline & $\begin{array}{l}\text { Human pancreas } \\
\text { carcinoma cells }\end{array}$ & $\begin{array}{l}\text { Stimulation of migration } \\
\text { and cytolytic activity of } \\
\text { natural killer cells }\end{array}$ & {$[86]$} \\
\hline & Human colon carcinoma & & [86] \\
\hline & cells & & [87] \\
\hline & $\begin{array}{l}\text { Human hepatocellular } \\
\text { carcinoma cells }\end{array}$ & & \\
\hline \multirow[t]{4}{*}{ Hsp90 } & $\begin{array}{l}\text { Human hepatocellular } \\
\text { carcinoma cells }\end{array}$ & $\begin{array}{l}\text { Stimulation of migration } \\
\text { and cytolytic activity of } \\
\text { natural killer cells }\end{array}$ & [87] \\
\hline & Glioblastoma cells & Cancer cells motility & {$[88]$} \\
\hline & Fibrosarcoma cells & & [88] \\
\hline & Breast cancer cells & & {$[88]$} \\
\hline \multirow[t]{5}{*}{ Hsp60 } & Human Erythroleukemia & Immunomodulatory & {$[13]$} \\
\hline & cells & functions (?) & {$[13]$} \\
\hline & $\begin{array}{l}\text { Human lung } \\
\text { adenocarcinoma }\end{array}$ & & \\
\hline & $\begin{array}{l}\text { Human mucoepidermoid } \\
\text { bronchial carcinoma }\end{array}$ & & {$[13,33]$} \\
\hline & $\begin{array}{l}\text { Human hepatocellular } \\
\text { carcinoma cells }\end{array}$ & $\begin{array}{l}\text { Stimulation of migration } \\
\text { and cytolytic activity of } \\
\text { natural killer cells }\end{array}$ & [87] \\
\hline
\end{tabular}

Table 1. Origin and hypothetic functions of tumoural exosomal Hsps 
blood [76]. In the cytosol, Hsps may play two distinct roles, given the numerous evidence implying that Hsps have pro-survival effects, while under different conditions they have been shown to have pro-apoptotic effects [92]. It is known that circulating Hsp can have immunosuppressing or immunostimulating effects, depending on the interaction between Hsps and cells or immune system components. For example, Hsp60 has been found in the blood of patients with Hashimoto's Thyroiditis (HT) and its presence may be involved in HT pathogenesis via an antibody mediated immune mechanism [94]. Moreover, extracellular Hsp60 can interact with a variety of receptors present on the surface of plasma cells, such as TLR, CD14, CD40 and CD91 [59]. Furthermore, Hsp60 appears to be involved in the activation of macrophages and neutrophils in patients with chronic lung diseases [95]. Levels of Hsp60 are increased in many types of tumours and it has been hypothesized that Hsp60 overexpression has an important role in cancer development and progression [65]. The use of Hsp60 as a biomarker for disease has recently been proposed and some researchers are studying the use of potential Hsp60 inhibitor agents in the treatment of certain diseases, including cancer [64, 96]. In heart failure, Hsp60 is released by cardiomyocytes and its presence in the serum may be correlated with the severity of the disease and cardiovascular risk [77, 97]. Moreover, Gupta and Knowlton [98] demonstrated that Hsp60 is released by adult cardiomyocytes through an exosome-mediated process in both the basal state and following mild stress. Another group of researchers demonstrated that fibrosarcoma cells release Hsp60 through the conventional endoplasmic reticulum Golgi protein transport pathway [99]. More recently, our research group showed that Hsp60 is released by tumour cells and not by normal cells, and that the mechanism of release is mediated by an unconventional secretion mechanism, i.e., the lipid raft exosome pathway [13]. These findings suggest a new role for extracellular Hsp60 in the cross-talk between tumour cells and the immune system [33, 99]. In fact, the expression of Hsp60 on the surface of exosomes released by tumour cells may be considered as a danger signal for the immune system [33]. Further studies are certainly needed to explain the unusual exosome membrane localization of Hsps [33, 100]. Experimental data show that exosomal Hsps may have opposing roles, that is, immunosuppressing or immunostimulating effects. These different effects depend on the interaction between exosomal Hsps and cells or immune system components. For example, it has been demonstrated that the histone deacetylase inhibitor, MS-275, can significantly alter the immune molecule content and categories in exosomes of hepatocarcinoma cells; in particular, treatment with MS-275 increased the expression of Hsp70. Exosome modification by MS-275 can significantly increase the cytotoxicity of NK cells and the proliferation of $\mathrm{PBMC}$, determining a reduction in tumour growth [101-104]. On the other hand, designing inhibitors of Hsp-associated exosomes may be useful to hindering the dissemination of metastases [88]. Moreover, the presence of Hsps associated with circulating exosomes can be evaluated and monitored quantitatively in the blood of patients with tumours associated with over-expression of one or more Hsps.

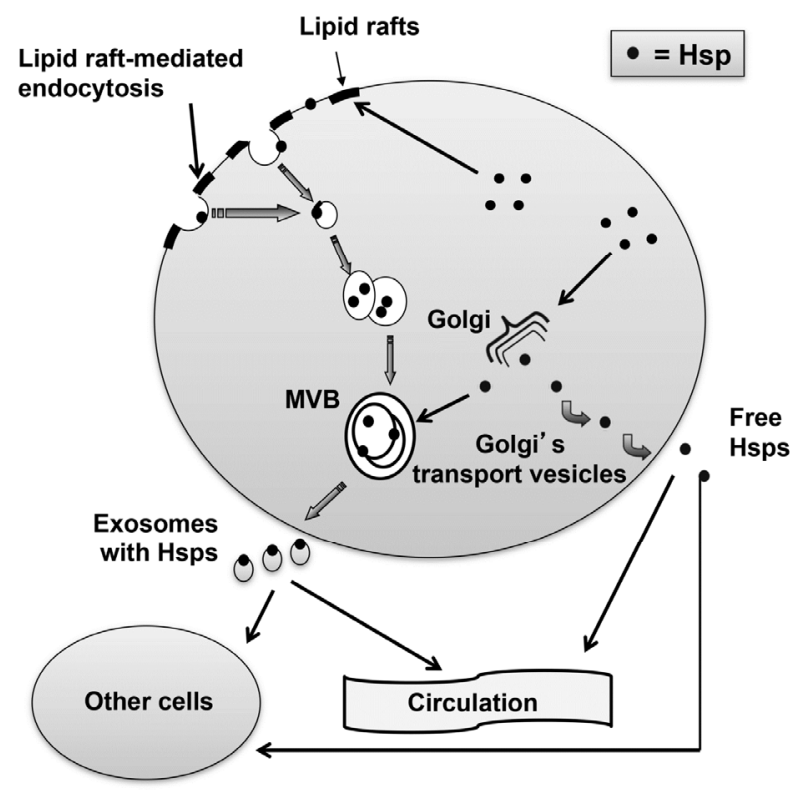

Figure 1. Pathways of secretion of heat shock proteins (Hsps) by tumour cells. Cytosolic Hsps can be released in free, soluble forms by Golgi transport vesicles or can be bound to exosomes. The latter is produced by multivesicular bodies (MVB) fusing with the plasma membrane of cells. Lipid rafts participate in Hsps release by exosomes, as they are internalized by endocytosis, which for various reasons that remain unknown reach the plasma membrane of tumour cells, and enter into MVB. Secreted Hsps may interact with other cells in the peritumoural environment or be released into the bloodstream.

\section{Conclusions}

Exosomes are currently considered to be bioactive vesicles that are useful in the study of normal biological functions, but also for understanding pathological conditions. The molecular composition of exosomes reflects the specialized functions of the original cells. Through exosomal ability to bind target cells and/or exchange molecules, they can modulate the activity of other cells. Hsps were originally described as intracellular molecular chaperones with a cytoprotective role. However, more novel functions have now been attributed to the Hsp proteins, depending on their localization. In particular, circulating Hsps (free or associated to exosomes) have immunological functions and may be involved in tumour progression [see Figure 1]. 
Hsps found on the surface of exosomes secreted by normal and tumour cells might be key players in intercellular cross-talk. There could be a novel and interesting link between Hsps and the immune system. Elsner et al. [101] demonstrated that Hsp70-positive exosomes released by tumour cells increase the NK cell activity against cell targets, resulting in reduced tumour growth. Therefore, exosomes can function as independent cell-to-cell carriers. Effectively, the immune response can be facilitated and enhanced by exosomes and their immunomodulatory molecules (such as Hsp70, 80, 90 and MHC class I molecules), released by the cell source into the blood [102]. Exosomes secreted by tumour cells and engineered to express specific Hsp molecules could improve antitumor immunity [105]. Therefore, engineered exosomes could be used as potential tumour vaccines or immunotherapeutic vesicles. Indeed, exosomes and their molecular cargo, including Hsps, are essential players in cell-to-cell communication and immunoregulation. There is significant potential for future clinical applications, including the use of Hsps as potential novel biomarkers for the diagnoses, prognoses and follow-up of different diseases, or for therapeutic applications and drug delivery. In particular, in light of new technical approaches, the levels of exosomes in human body fluids can be detected and quantified [106], and it is clear that exosomes have the potential to become important circulating biomarkers in the vast majority of human diseases [107]. Moreover, their intriguing capacity to shuttle molecules of various origins may well become one of the most important available drug delivery systems; they may therefore be of paramount importance for the future of nanomedicine [108].

\section{Compliance with ethical research standards}

Conflict of interest - The authors declare no conflicts of interest

\section{References}

[1] Raposo G, Stoorvogel W (2013) Extracellular vesicles: exosomes, microvesicles, and friends. J. Cell Biol. 18;200(4):373-383.

[2] Camussi G, Deregibus MC, Bruno S, Cantaluppi V, Biancone L (2010) Exosomes/microvesicles as a mechanism of cell-to-cell communication. Kidney Int. 78(9):838-848.

[3] Bartel DP (2004) MicroRNAs: genomics, biogenesis, mechanism, and function. Cell. 116(2):281-297.

[4] Kinet V, Halkein J, Dirkx E, Windt LJ (2013) Cardiovascular extracellular microRNAs: emerging diagnostic markers and mechanisms of cell-to-cell RNA communication. Front. Genet. 4:214.

[5] Tetta C, Ghigo E, Silengo L, Deregibus MC, Camussi G (2013) Extracellular vesicles as an emerging mechanism of cell-to-cell communication. Endocrine 44(1):11-19.

[6] Lopez-Verrilli MA, Court FA (2013) Exosomes: mediators of communication in eukaryotes. Biol. Res. 46(1):5-11.

[7] Kim J, Morley S, Le M, Bedoret D, Umetsu DT, Di Vizio D, Freeman M R (2014) Enhanced shedding of extracellular vesicles from amoeboid prostate cancer cells: Potential effects on the tumor microenvironment. Cancer Biol. Ther. 15(4) :409-418

[8] Wolf P (1967) The nature and significance of platelet products in human plasma. Br. J. Haematol. 13:269-288.

[9] Johnstone RM, Adam M, Hammond JR, Orr L, Turbide C (1987) Vesicle formation during reticulocyte maturation. Association of plasma membrane activities with released vesicles (exosomes). J. Biol. Chem. 262(19):9412-9420.

[10] Raposo G, Nijman HW, Stoorvogel W, Liejendekker R, Harding CV, Melief CJ, Geuze HJ (1996) B lymphocytes secrete antigen-presenting vesicles. J. Exp. Med. 183(3):1161-1172.

[11] van Niel G, Porto-Carreiro I, Simoes S, Raposo G (2006) Exosomes: a common pathway for a specialized function. J. Biochem. 140(1):13-21.

[12] Théry C, Regnault A, Garin J, Wolfers J, Zitvogel L, Ricciardi-Castagnoli P, Raposo G, Amigorena S (1999) Molecular characterization of dendritic cellderived exosomes. Selective accumulation of the heat shock protein hsc73. J. Cell. Biol. 147(3):599-610.

[13] Merendino AM, Bucchieri F, Campanella C, Marcianò V, Ribbene A, David S, Zummo G, Burgio G, Corona DF, Conway de Macario E, Macario AJ, Cappello F (2010) Hsp60 is actively secreted by human tumor cells. PLoS One. 5(2):e9247. doi: 10.1371/journal.pone.0009247.

[14] Balaj L, Lessard R, Dai L, Cho YJ, Pomeroy SL, Breakefield XO, Skog J (2011) Tumour microvesicles contain retrotransposon elements and amplified oncogene sequences. Nat. Commun. 2:180.

[15] Turiák L, Misják P, Szabó TG, Aradi B, Pálóczi K, Ozohanics O, Drahos L, Kittel A, Falus A, Buzás EI, Vékey K (2011) Proteomic characterization of thymocyte-derived microvesicles and apoptotic bodies in BALB/c mice. J. Proteomics. 74(10):2025-2033.

[16] Simpson RJ, Jensen SS, Lim JW (2008) Proteomic profiling of exosomes: current perspectives. Proteomics. 8(19):4083-4099.

[17] Pan BT, Blostein R, Johnstone RM (1983) Loss of the transferrin receptor during the maturation of sheep reticulocytes in vitro. An immunological approach. Biochem. J. 210(1):37-47.

[18] Vlassov AV, Magdaleno S, Setterquist R, Conrad R (2012) Exosomes: current knowledge of their composition, biological functions, and diagnostic and therapeutic potentials. Biochim. Biophys. Acta. 1820(7):940-948. 
[19] van Niel G, Porto-Carreiro I, Simoes S, Raposo G. (2006) Exosomes: a common pathway for a specialized function. J. Biochem. 140(1):13-21.

[20] Colombo M, Moita C, van Niel G, Kowal J, Vigneron J, Benaroch P, Manel N, Moita LF, Théry C, Raposo G (2013) Analysis of ESCRT functions in exosome biogenesis, composition and secretion highlights the heterogeneity of extracellular vesicles. J. Cell Sci. 126(4):5553-5565.

[21] Buschow SI, van Balkom BW, Aalberts M, Heck AJ, Wauben M, Stoorvogel W (2010) MHC class IIassociated proteins in B-cell exosomes and potential functional implications for exosome biogenesis. Immunol. Cell Biol. 88(8):851-856.

[22] Babst M (2005) A Protein's Final ESCRTs. Traffic. 6:2-9.

[23] Trajkovic K, Hsu C, Chiantia S, Rajendran L, Wenzel D, Wieland F, Schwille P, Brügger B, Simons M (2008) Ceramide triggers budding of exosome vesicles into multivesicular endosomes. Science. 319(5867):1244-1247.

[24] Hemler ME (2001) Specific tetraspanin functions. J. Cell Biol. 155(7):1103-7.

[25] Mears R, Craven RA, Hanrahan S, Totty N, Upton C, Young SL, Patel P, Selby PJ, Banks RE (2004) Proteomic analysis of melanoma-derived exosomes by two dimensional polyacrylamide gel electrophoresis and mass spectrometry. Proteomics. 4:4019-4031.

[26] Thery C Zitvogel L Amigorena S (2002) Exosomes: Composition, biogenesis and function. Nat. Rev. Immunol. 2:569-579.

[27] Hegmans JP, Bard MP, Hemmes A, Luider TM, Kleijmeer MJ, Prins JB, Zitvogel L, Burgers SA, Hoogsteden HC, Lambrecht BN (2004) Proteomic analysis of exosomes secreted by human mesothelioma cells. Am. J. Pathol. 164:1807-1815.

[28] Huber V, Fais S, Iero M, Lugini L, Canese P, Squarcina P, Zaccheddu A, Colone M, Arancia G, Gentile M, Seregni E, Valenti R, Ballabio G, Belli F, Leo E, Parmiani G, Rivoltini L (2005) Human colorectal cancer cells induce T-cell death through release of proapoptotic microvesicles: Role in immune escape. Gastroenterology 128:1796-1804.

[29] Soderberg A, Barral AM, Soderstrom M, Sander B, Rosen A (2007) Redox-signaling transmitted in trans to neighboring cells by melanoma-derived TNFcontaining exosomes. Free Radic. Biol. Med. 43:90-99.

[30] Clayton A, Mitchell JP, Court J, Mason MD, Tabi Z, (2007) Human tumor-derived exosomes selectively impair lymphocyte responses to interleukin-2. Cancer Res. 67:7458-7466.

[31] Taylor DD, Gercel-Taylor C (2005) Tumour-derived exosomes and their role in cancer-associated T-cell signalling defects. Br. J. Cancer 92:305-311

[32] Denzer K, Kleijmeer MJ, Heijnen HF, Stoorvogel W, Geuze HJ (2000) Exosome: From internal vesicle of the multivesicular body to intercellular signaling device. J. Cell Sci. 113:3365-3374.
[33] Campanella C, Bucchieri F, Merendino AM, Fucarino A, Burgio G, Corona DF, Barbieri G, David S, Farina F, Zummo G, de Macario EC, Macario AJ, Cappello F (2012) The odyssey of Hsp60 from tumor cells to other destinations includes plasma membrane-associated stages and Golgi and exosomal protein-trafficking modalities. PLoS One. 7(7):e42008. doi: 10.1371/journal.pone.0042008

[34] Mathew A, Bell A, Johnstone RM (1995) Hsp-70 is closely associated with the transferrin receptor in exosomes from maturing reticulocytes. Biochem. J.308:823-830.

[35] Crescitelli R, Lässer C, Szabó TG, Kittel A, Eldh M, Dianzani I, Buzás EI, Lötvall J (2013) Distinct RNA profiles in subpopulations of extracellular vesicles: apoptotic bodies, microvesicles and exosomes. J. Extracell. Vesicles 2. doi: 10.3402/jev.v2i0.20677.

[36] Villarroya-Beltri C, Gutiérrez-Vázquez C, SánchezMadrid F, Mittelbrunn M (2013) Analysis of microRNA and protein transfer by exosomes during an immune synapse. Methods Mol. Biol. 1024:41-51.

[37] Van den Boorn JG, Dassler J, Coch C, Schlee M, Hartmann G (2013) Exosomes as nucleic acid nanocarriers. Adv Drug Deliv Rev. 65(3): 331-5.

[38] Valadi H, Ekstrom K, Bossios A, Sjostrand M, Lee JJ, Lotvall J (2007) Exosomes-mediated transfer of mRNAs and microRNAs is novel mechanism of genetic exchange between cells. Nat. Cell Biol. 9(6):654-9.

[39] Eldh M, Ekstrom K, Valadi H, Sjostrand M, Olsson B, Jernas M, Lotvall J (2010) Exosomes communicate protective messages during oxidative stress; possible role of exosomal shuttle RNA. PlosOne; 5(12):e15353 doi: 10.1371/journal.pone.0015353.

[40] Schageman K, Zeringer E, Li M, Barta T, Lea K, Gu J, Magdaleno S, Setterquist R, Vlassov AV (2013) The complete exosome workflow solution: from isolation to characterization of RNA cargo. Biomed. Res. Int; 253957: doi: 10.1155/2013/253957

[41] Nolte'-t Hoen ENM; Buermans HPJ, Waasdorp M, Stoorvogel W, Wauben MHM, 't Hoen PAC (2012) Deep sequencing of RNA from immune cell-derived vesicles uncovers the selective incorporation of small non-coding RNA biotypes with potential regulatory functions. Nucleic Acid Res. 40(18)9272:85.

[42] Mathivanan S, Ji H, Simpson RJ, (2010) Exosomes: extracellular organelles important in intercellular communication. J. Proteomics. 73(10):1907-1920.

[43] Kotzerke K, Mempel M, Aung T, Wulf GG, Urlaub H, Wenzel D, Schön MP, Braun A (2013) Immunostimulatory activity of murine keratinocytederived exosomes. Exp. Dermatol. 22(10):650-655.

[44] Kulshreshtha A, Ahmad T, Agrawal A, Ghosh B. (2013) Proinflammatory role of epithelial cell-derived exosomes in allergic airway inflammation. J. Allergy Clin. Immunol. 131(4):1194-203. 
[45] Janowska-Wieczorek A, Wysoczynski M, Kijowski J, Marquez-Curtis L, Machalinski B, Ratajczak J, Ratajczak MZ (2005) Microvesicles derived from activated platelets induce metastasis and angiogenesis in lung cancer. Int. J. Cancer 113(5):752-60.

[46] Camussi G, Deregibus MC, Cantaluppi V (2013) Role of stem-cell-derived microvesicles in the paracrine action of stem cells. Biochem. Soc. Trans. 41(1):283-7.

[47] Stenqvist AC, Nagaeva O, Baranov V, MinchevaNilsson (2013) L.Exosomes secreted by human placenta carry functional Fas ligand and TRAIL molecules and convey apoptosis in activated immune cells, suggesting exosome-mediated immune privilege of the fetus. J. Immunol. 191(11):5515-5523.

[48] Clayton A, Turkes A, Navabi H, Mason MD, Tabi Z (2005) Induction of heat shock proteins in B-cell exosomes. J. Cell Sci. 118(16):3631-3638.

[49] Klöhn PC, Castro-Seoane R, Collinge J (2013) Exosome release from infected dendritic cells: a clue for a fast spread of prions in the periphery? J. Infect. 67(5):359-68.

[50] Yamada T, Shigemura H, Ishiguro N, Inoshima $Y$ (2013) Cell Infectivity in relation to bovine leukemia virus gp51 and p24 in bovine milk exosomes. PLoS One. 17;8(10):e77359.

[51] Ogorevc E, Kralj-Iglic V, Veranic P (2013) The role of extracellular vesicles in phenotypic cancer transformation. Radiol. Oncol. 47(3):197-205.

[52] Zöller M (2013) Pancreatic cancer diagnosis by free and exosomal miRNA. World J. Gastrointest. Pathophysiol. 4(4):74-90.

[53] Szajnik M, Derbis M, Lach M, Patalas P, Michalak M, Drzewiecka H, Szpurek D, Nowakowski A, Spaczynski M, Baranowski W, Whiteside TL (2013) Exosomes in Plasma of Patients with Ovarian Carcinoma: Potential Biomarkers of Tumor Progression and Response to Therapy. Gynecol Obstet. (Sunnyvale). Suppl 4:3.

[54] Liu T, Mendes DE, Berkman CE (2014) Functional prostate-specific membrane antigen is enriched in exosomes from prostate cancer cells. Int. J. Oncol. 44(3):918-22.

[55] Duijvesz D, Burnum-Johnson KE, Gritsenko MA, Hoogland AM, Vredenbregt-van den Berg MS, Willemsen R, Luider T, Paša-Tolić L, Jenster G (2013) Proteomic profiling of exosomes leads to the identification of novel biomarkers for prostate cancer. PLoS One. 31;8(12):e82589.

[56] Tasaki M, Ueda M, Ochiai S, Tanabe Y, Murata S, Misumi Y, Su Y, Sun X, Shinriki S, Jono H, Shono M, Obayashi K, Ando Y (2010) Transmission of circulating cell-free AA amyloid oligomers in exosomes vectors via a prion-like mechanism. Biochem. Biophys. Res. Commun. 400(4):559-562.
[57] Lee Y, El Andaloussi S, Wood MJ (2012) Exosomes and microvesicles: extracellular vesicles for genetic information transfer and gene therapy. Hum. Mol. Genet. 21(R1):R125-34.

[58] Andreola G, Rivoltini L, Castelli C, Huber V, Perego P, Deho P, Squarcina P, Accornero P, Lozupone F, Lugini L, Stringaro A, Molinari A, Arancia G, Gentile M, Parmiani G, Fais S (2002) Induction of lymphocyte apoptosis by tumor cell secretion of FasL-bearing microvesicles. J. Exp. Med. 20; 195(10):1303-16.

[59] Huber V, Fais S, Iero $M$, Lugini $L$, Canese $P$, Squarcina P, Zaccheddu A, Colone M, Arancia G, Gentile M, Seregni E, Valenti R, Ballabio G, Belli F, Leo E, Parmiani G, Rivoltini L (2005) Human colorectal cancer cells induce T-cell death through release of proapoptotic microvesicles: role in immune escape. Gastroenterology. 128(7):1796-804.

[60] Lugini L, Cecchetti S, Huber V, Luciani F, Macchia G, Spadaro F, Paris L, Abalsamo L, Colone M, Molinari A, Podo F, Rivoltini L, Ramoni C, Fais S (2012) Immune surveillance properties of human NK cellderived exosomes. J. Immunol. 15;189(6):2833-42.

[61] Parolini I, Federici C, Raggi C, Lugini L, Palleschi S, De Milito A, Coscia C, Iessi E, Logozzi M, Molinari A, Colone M, Tatti M, Sargiacomo M, Fais S (2009) Microenvironmental $\mathrm{pH}$ is a key factor for exosome traffic in tumor cells. J. Biol. Chem. 4;284(49):34211-22.

[62] Fais S (2013) NK cell-released exosomes: Natural nanobullets against tumors. Oncoimmunology. 1;2(1):e22337.

[63] Macario AJL and Conway de Macario E (2008/2009) The chaperoning system: Physiology and pathology. In Gerbino A, Crescimanno G and Zummo G (Eds.) Experimental Medicine Reviews pp. 9-21.

[64] Cappello F, Marino Gammazza A, Palumbo Piccionello A, Campanella C, Pace A, Conway de Macario E, Macario AJ (2014) Hsp60 chaperonopathies and chaperonotherapy: targets and agents. Expert Opin. Ther. Targets. 18(2):185-208.

[65] Rappa F, Farina F, Zummo G, David S, Campanella C, Carini F, Tomasello G, Damiani P, Cappello F, DE Macario EC, Macario AJ. Rappa F (2012) HSPmolecular chaperones in cancer biogenesis and tumor therapy: an overview. Anticancer Res. 32(12):5139-50.

[66] Calderwood SK, Stevenson MA, Murshid A (2012) Heat shock proteins, autoimmunity, and cancer treatment. Autoimmune Dis. 2012:486069.

[67] Lindquist S (1986) The heat-shock response. Ann. Rev. Biochem. 55:1151-1191.

[68] Macario AJL, Conway de Macario E, Cappello F. (2013) Chapter 2 - Chaperones: General Characteristics and Classifications. In The Chaperonopathies Diseases with defective Molecular Chaperones. Ed Springer Briefs in Biochemestry and Molecular Biology. pp15-30. 
[69] Jego G, Chiron D, Berthenet K, Pellat-Deceunynck C (2012). Modulation of normal and malignant plasma cells function by toll-like receptors. Front. Biosci. 4:2289-301.

[70] Tamura Y, Torigoe T, Kutomi G, Hirata K, Sato N (2012) New paradigm for intrinsic function of heat shock proteins as endogenous ligands in inflammation and innate immunity. Curr. Mol. Med. 12(9):1198-206.

[71] Van Eden W, Wick G, Albani S, Cohen I (2007) Stress, heat shock proteins, and autoimmunity: how immune responses to heat shock proteins are to be used for the control of chronic inflammatory diseases. Ann N Y Acad. Sci. 1113:217-37.

[72] Fagone P, Di Rosa M, Palumbo M, De Gregorio C, Nicoletti F, Malaguarnera L (2012) Modulation of heat shock proteins during macrophage differentiation. Inflamm. Res. 61(10):1131-1139.

[73] Campanella C, Bucchieri F, Ardizzone NM, Marino Gammazza A, Montalbano A, Ribbene A, Di Felice V, Bellafiore M, David S, Rappa F, Marasà M, Peri G, Farina F, Czarnecka AM, Conway de Macario E, Macario AJ, Zummo G, Cappello F (2008) Upon oxidative stress, the antiapoptotic Hsp60/procaspase3 complex persists in mucoepidermoid carcinoma cells. Eur. J. Histochem. 52(4):221-228.

[74] Czarnecka AM, Campanella C, Zummo G, Cappello F (2006) Mitochondrial chaperones in cancer: from molecular biology to clinical diagnostics. Cancer Biol. Ther. 5(7):714-720.

[75] Cappello F, Conway de Macario E, Marasà L, Zummo G, Macario AJ (2008) Hsp60 expression, new locations, functions and perspectives for cancer diagnosis and therapy. Cancer Biol. Ther. 7(6):801809.

[76] Rizzo M, Cappello F, Marfil R, Nibali L, Marino Gammazza A, Rappa F, Bonaventura G, GalindoMoreno P, O'Valle F, Zummo G, Conway de Macario E, Macario AJ, Mesa F (2012) Heat-shock protein 60 $\mathrm{kDa}$ and atherogenic dyslipidemia in patients with untreated mild periodontitis: a pilot study. Cell Stress Chaperones. 17(3):399-407

[77] Bonanad C, Núñez J, Sanchis J, Bodi V, Chaustre F, Chillet M, Miñana G, Forteza MJ, Palau P, Núñez E, Navarro D, Llàcer A, Chorro FJ (2013) Serum heat shock protein 60 in acute heart failure: a new biomarker? Congest. Heart Fail. 19(1):6-10.

[78] Ireland HE, Leoni F, Altaie O, Birch CS, Coleman RC, Hunter-Lavin C, Williams JH (2007) Measuring the secretion of heat shock proteins from cells. Methods. 43(3):176-183.

[79] Graner MW, Cumming RI, Bigner DD (2007) The heat shock response and chaperones/heat shock proteins in brain tumors: surface expression, release, and possible immune consequences. J. Neurosci. 27(42):11214-11227.
[80] Febbraio MA, Ott P, Nielsen HB, Steensberg A, Keller C, Krustrup P, Secher NH, Pedersen BK (2002) Exercise induces hepatosplanchnic release of heat shock protein 72 in humans. J. Physiol. 544(3):957-962.

[81] Rea IM, McNerlan S, Pockley AG (2001) Serum heat shock protein and anti-heat shock protein antibody levels in aging. Exp. Gerontol. 36(2):341-52.

[82] Calderwood SK, Mambula SS, Gray PJ Jr, Theriault JR (2007) Extracellular heat shock proteins in cell signaling. FEBS Lett. 581(19):3689-94.

[83] Multhoff G, Hightower LE (1996) Cell surface expression of heat shock proteins and the immune response. Cell Stress Chaperones. 1(3):167-76.

[84] Lancaster GI, Febbraio MA (2005) Exosomedependent trafficking of HSP70: a novel secretory pathway for cellular stress proteins. J. Biol. Chem. 280(24):23349-23355.

[85] Bausero MA, Gastpar R, Multhoff G, Asea A (2005) Alternative mechanism by which IFN-gamma enhances tumor recognition: active release of heat shock protein 72. J. Immunol. 175(5):2900-2912.

[86] Gastpar R, Gehrmann M, Bausero MA, Asea A, Gross C, Schroeder JA, Multhoff G (2005) Heat shock protein 70 surface-positive tumor exosomes stimulate migratory and cytolytic activity of natural killer cells. Cancer Res. 65(12):5238-5247.

[87] Lv LH, Wan YL, Lin Y, Zhang W, Yang M, Li GL, Lin HM, Shang CZ, Chen YJ, Min J (2012) Anticancer drugs cause release of exosomes with heat shock proteins from human hepatocellular carcinoma cells that elicit effective natural killer cell antitumor responses in vitro. J. Biol. Chem. 287(19):15874-15885.

[88] McCready J, Sims JD, Chan D, Jay DG (2010) Secretion of extracellular hsp90alpha via exosomes increases cancer cell motility: a role for plasminogen activation. BMC Cancer. 10:294.

[89] Zhan R, Leng X, Liu X, Wang X, Gong J, Yan L, Wang L, Wang Y, Wang X, Qian LJ (2009) Heat shock protein 70 is secreted from endothelial cells by a nonclassical pathway involving exosomes. Biochem. Biophys. Res. Commun. 387(2):229-233

[90] Vega VL, Rodríguez-Silva M, Frey T, Gehrmann M, Diaz JC, Steinem C, Multhoff G, Arispe N, De Maio A (2008) Hsp70 translocates into the plasma membrane after stress and is released into the extracellular environment in a membrane-associated form that activates macrophages. J. Immunol. 180(6):4299-4307.

[91] Caruso Bavisotto C, Marino Gammazza A, Rappa F, Fucarino A, Pitruzzella A, David S, Campanella C (2013) Exosomes: can doctors still ignore their existence? EuroMediterranean Biomedical Journal. 8(22):137-139.

[92] Chandra D, Choy G, Tang DG (2007) Cytosolic accumulation of HSP60 during apoptosis with or without apparent mitochondrial release: evidence that its pro-apoptotic or pro-survival functions involve differential interactions with caspase-3. J. Biol. Chem. 282(43):31289-31301. 
[93] Soltys BJ, Gupta RS. (1996) Immunoelectron microscopic localization of the $60-\mathrm{kDa}$ heat shock chaperonin protein (Hsp60) in mammalian cells. Exp. Cell Res. 222(1):16-27.

[94] Marino Gammazza A, Rizzo M, Citarrella R, Rappa F, Campanella C, Bucchieri F, Patti A, Nikolic D, Cabibi D, Amico G, Conaldi PG, San Biagio PL, Montalto G, Farina F, Zummo G, Conway de Macario E, Macario AJ, Cappello F. (2013) Elevated blood Hsp60, its structural similarities and crossreactivity with thyroid molecules, and its presence on the plasma membrane of oncocytes point to the chaperonin as an immunopathogenic factor in Hashimoto's thyroiditis. Cell Stress Chaperones. doi 10.1007/s12192-013-0460-9

[95] Cappello F, Caramori G, Campanella C, Vicari C, Gnemmi I, Zanini A, Spanevello A, Capelli A, La Rocca G, Anzalone R, Bucchieri F, D'Anna SE, Ricciardolo FL, Brun P, Balbi B, Carone M, Zummo G, Conway de Macario E, Macario AJ, Di Stefano A (2011) Convergent sets of data from in vivo and in vitro methods point to an active role of Hsp60 in chronic obstructive pulmonary disease pathogenesis. PLoS One. 6(11):e28200.

[96] Pace A, Barone G, Lauria A, Martorana A, Piccionello AP, Pierro P, Terenzi A, Almerico AM, Buscemi S, Campanella C, Angileri F, Carini F, Zummo G, de Macario EC, Cappello F, Macario AJ (2013) Hsp60, a novel target for antitumor therapy: structurefunction features and prospective drugs design. Curr. Pharm. Des. 19(15):2757-64.

[97] Nahas EA, Nahas-Neto J, Orsatti CL, Tardivo AP, Uemura G, Peraçoli MT, Witkin SS (2013) The 60and $70-\mathrm{kDa}$ heat-shock proteins and their correlation with cardiovascular risk factors in postmenopausal women with metabolic syndrome. Cell Stress Chaperones. doi 10.1007/s12192-013-0483-2

[98] Gupta S, Knowlton AA (2007) HSP60 trafficking in adult cardiac myocytes: role of the exosomal pathway. Am J Physiol. Heart Circ. Physiol. 292(6):H3052-3056.

[99] Hayoun D, Kapp T, Edri-Brami M, Ventura T, Cohen M, Avidan A, Lichtenstein RG (2012) HSP60 is transported through the secretory pathway of 3-MCAinduced fibrosarcoma tumour cells and undergoes Nglycosylation. FEBS J. 279(12):2083-2095.

[100] Radons J, Multhoff G (2005) Immunostimulatory functions of membrane-bound and exported heat shock protein 70. Exerc. Immunol. Rev. 11:17-33.
[101] Elsner L, Muppala V, Gehrmann M, Lozano J, Malzahn D, Bickeböller H, Brunner E, Zientkowska M, Herrmann T, Walter L, Alves F, Multhoff G, Dressel R (2007) The heat shock protein HSP70 promotes mouse NK cell activity against tumors that express inducible NKG2D ligands. J. Immunol. 15;179(8):5523-33.

[102] Xiao W, Dong W, Zhang C, Saren G, Geng P, Zhao H, Li Q, Zhu J, Li G, Zhang S, Ye M (2013) Effects of the epigenetic drug MS-275 on the release and function of exosome-related immune molecules in hepatocellular carcinoma cells. Eur. J. Med. Res. 23; 18:61. doi: 10.1186/2047-783X-18-61.

[103] Li QW, Xiao WH, Sarengaowa G, Dong WW, Zhao HX, Duan XY, Zhu JH, Kang HR, Fu Y, Hao YX, Wang RL, Song LP, Ye M. Histone deacetylase inhibitor MS-275 treatment alters immune molecule content and categories in hepatocarcinoma exosomes Zhonghua Gan Zang Bing Za Zhi. 2012 Mar;20(3):231-5. doi: 10.3760/cma.j.issn.10073418.2012.03.019.

[104] Franzen CA, Simms PE, Van Huis AF, Foreman KE, Kuo PC, Gupta GN (2014) Characterization of uptake and internalization of exosomes by bladder cancer cells. Biomed. Res. Int.;2014:619829. doi: $10.1155 / 2014 / 619829$.

[105] Xie Y, Bai O, Zhang H, Yuan J, Zong S, Chibbar R, Slattery K, Qureshi M, Wei Y, Deng Y, Xiang J (2010) Membrane-bound HSP70-engineered myeloma cell derived exosomes stimulate more efficient CD8(+) CTL- and NK-mediated antitumour immunity than exosomes released from heat-shocked tumor cells expressing cytoplasmic HSP70. J. Cell. Mol. Med. 14(11):2655-66. doi: 10.1111/j.1582-4934.2009.00851.x.

[106] Logozzi M, De Milito A, Lugini L, Borghi M, Calabrò L, Spada $M$, Perdicchio $M$, Marino ML, Federici C, Iessi E, Brambilla D, Venturi G, Lozupone F, Santinami M, Huber V, Maio M, Rivoltini L, Fais S (2009) High levels of exosomes expressing CD63 and caveolin-1 in plasma of melanoma patients. PLoS One. 4(4):e5219.

[107] Properzi F, Logozzi M, Fais S (2013) Exosomes: the future of biomarkers in medicine. Biomark. Med. 7(5):769-78.

[108] Fais S, Logozzi M, Lugini L, Federici C, Azzarito T, Zarovni N, Chiesi A (2013) Exosomes: the ideal nanovectors for biodelivery. Biol. Chem. 394(1):1-15. 